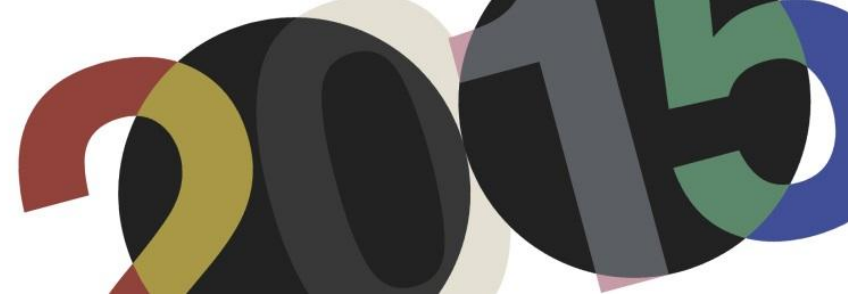

DOI: http://dx.doi.org/10.4995/LC2015.2015.862

\title{
Summer houses in Portugal: the legacy of the Exitenzminimum and the work of Le Corbusier
}

\section{T. Freitas}

Faculdade de Arquitectura da Universidade do Porto

\begin{abstract}
The program of the summer house will mark the acceptance period of modern architecture in Portugal. The modern life is put into practice by a group of architects to an enlightened bourgeoisie clientele, in some summer resorts that will start to be developed in the Portuguese coastline.

The Existenzminimum, will be a German expression used throughout the twentieth century, particularly after the First World War, where the concerns of social nature and housing, for a large number of people will be important issues to be discussed by architects. Petit cabanon was Le Corbusier's summer house in Roquebrune-Cap-Martin. This small pavilion experienced new possibilities of living in minimum area, similar to the theories of the existenzminimum studied by Modern architects in the post-first world war period. New ways to dwell in minimum space are then reinterpreted in the early experiences of holiday houses in Portugal where a simple way of living started to be tested.
\end{abstract}

Resumen: El programa de la casa de verano se cumplirá el plazo de aceptación de la arquitectura moderna en Portugal. La vida moderna se pone en práctica por un grupo de arquitectos a una clientela de burguesía, en algunos centros turísticos de verano que comenzarán a desarrollar en la costa portuguesa.

El Existenzminimum, será una expresión alemana utilizado a lo largo del siglo XX, sobre todo después de la Primera Guerra Mundial, donde las preocupaciones de carácter social y vivienda, para un gran número de personas serán temas importantes a tratar por los arquitectos. Petit Cabanon fue la casa de verano de Le Corbusier en Roquebrune-Cap-Martin. Este pequeño pabellón experimentó nuevas posibilidades de vivir en área mínima, similar a las teorías de la Existenzminimum estudiados por arquitectos modernos en el periodo posterior a la primera guerra mundial. Nuevas formas de habitar el espacio mínimo son entonces reinterpretadas en las primeras experiencias de casas de vacaciones en Portugal, donde una forma moderna de habitar comenzó a ser testada.

Keywords: Petit cabanon; Le Corbusier; Holiday houses; Existenzminimum; Arquitecture; Modern.

Palabras clave: Petit cabanon; Le Corbusier; Casas de Verano; Existenzminimum; Arquitectura; Moderno.

\section{Introduction}

The modern summer house in Portugal will start to be developed in large scale between the decade of 1940 and 1960. This new program will give opportunity to a range of architects to test a new typology in direct relationship with the nature. Existenzminimum, will be the German expression for minimum housing, which began to be used regularly in the post First World War. A "minimum to a maximum" of people was the object. According to Ana Tostões ${ }^{1}$; this concern was felt in postwar Europe, with the aim of responding to the urgent need to create urban spaces from a consequence of centripetal social transformations, which shifted non-urban population in masses to the cities. That's how the architecture of this period becomes a concern of social consciousness. Architects such as Le Corbusier, Bruno Taut, Ernst May will make a research in the way of living

\footnotetext{
${ }^{1}$ Tostões, Ana, A idade maior. Cultura e tecnologia na arquitectura moderna potuguesa, FAUP ed., Porto,2015 [2003], P.302.
} 
in minimum space. Ten years later, in 1930, Le Corbusier will have the opportunity to work in projects for holiday houses around the world. In these houses, Le Corbusier investigates modern architecture, relating it with local materials and techniques. Maison Errazuriz, Maison Mandrot, Maison aux Mathes, Maison de Week-End and Maison Murondins are examples of this approach, " The vernacular materials are not an obstacle for a modern aestetique "2. In the decade of 1950, at Roquebrune-Cap-Martin, Le Corbusier experiments the standardization of space according to the modulor, in the cabanon he builds for Yvone the idyllic primitive hut. In Portugal these new attempts in modern architecture will have a large influence in the construction of the modern summer house. These small holiday pavilions will question the way man can live in modern housing. The primitive hut, the ideal getaway, and the "heterotopia" these houses build in pine forests along the sea create idyllic places in communion with nature where a group of elite bourgeoisie settles. It is here that the bourgeoisie created a core of families who meet year after year in the summer, and witnessed a new way to live, above all, more modern.

\section{Developing}

\subsection{The summer house in Portugal}

The summer residence will appear in Portugal at the end of the nineteenth century. Derived from the Roman villae, they became Palladian buildings in the Renaissance and later chalets. According to Rui Ramos, "This house appears as a synthesis between the farm house, the leisure house, or vacation of the upper classes, initially designated as cottage orné, characterized by the use of rustic materials and asymmetrical compositions" $^{3}$, these chalets give regard to a picturesque countryside and vocabulary in the Romantic period, abandoning the symmetries and looking for an organic relationship with the plot and the landscape.

In Portugal, Sintra becomes the ideal place for these new cottages where the romantic and eclectic taste will be dominant. Cascais or the Granja, and later the Estoril will be the seaside resorts of Portugal between 1865 and the 1930s. Conversely, from the decades 1930/1940, the search for a new architectural model of holiday house derived from the chalet begins. In the Rodizio, architects born in the 1910s where Keil do Amaral stands as a prominent figure, will begin testing new models of the holiday house.

From the late 1950s, and according to Ana Tostões ${ }^{4}$, a widespread acceptance of modern architecture by an elite bourgeoisie begins; one which will eventually be on the forefront of the development of new resorts in Portugal.

Here is where the new model of holiday houses will appear. According to Susana Lobo, these houses will be models "The former appearance, of the new, in several summer resorts along the coast, where the detached

\footnotetext{
2 "la rusticité des materiaux n`est aucunement une entrave à la manifestation d'un plan clair et d’une esthétique modern"translated by author from the french edition ; Le Corbusier; Jeanneret, Pierre, "Maison de M. Errazuriz, Au Chili, 1930", in Boesiger, W (dir.) Le Corbusier oeuvre complète, volume2, Les Editions d`Architecture (Artemis), Zúrich, 1964, P.48.

3 "Esta casa surge como síntese entre a casa agrícola e a casa de recreio ou de férias das classes altas, inicialmente designada como cottage orné, caracterizada pelo uso de materiais rústicos e composição assimétrica", translated by author from the portuguese edition; Ramos, Rui, A casa, Arquitectura e Projecto doméstico na primeira metade do século XX Português, FAUP publicações, Porto, 2010, P.78.

4 Tostões, Ana, "Casas de Férias modernas, anos 50 e estilo contemporâneo- A utopia de uma doce vida", in Jornal de Arquitectos, $N^{\circ}$ 196, Ordem dos Arquitectos, Lisboa.2000, P. 45-53.
} 
holiday house is presented as a true laboratory project, on domestic architecture"5 for a new model of modern living.

According to Rui Ramos ${ }^{6}$, the urbanization along the beaches from Ofir in the North to Rodízio in the South, reveals this new way of modern living. These resorts appear as places capable of providing the contact with nature, the despoliation of a number of domestic routines, which are now abandoned in favor of a more uncompromising and "modern" lifestyle. These holiday houses represent a new leisure time outside the main residence, the weekend and holiday in the countryside or at the beach.

The summer house attempts to be like a small pavilion, expirimenting the theories of Existenzminimum where the furniture is designed as an integral part of the architecture, the doors lose their formal value and become curtains, beds and bunk beds can be stacked and the living room becomes the central space of the house. The rooms are like sleeping alcoves, ressembling us ship or train cabins. The connection between the exterior and the interior becomes almost direct, made by large window panels adding to the continuity of the pavements in patios and terraces.

Examples of these formal researches around the holiday house in Portugal, are testimony in houses that are built from north to south of the country.

\subsection{Existenzminimum in the post-world war}

With Germany destroyed by World War I, the theme Existenzminimum, will gain more prominence, both in new housing construction as in the study of new ways of living. At the second meeting of CIAM, in Frankfurt in 1929, the concept of Existenzminimum, presents itself as a Claim. " During the congress participants struggled to formulate a program that reconciled the demands of physical creation of living space, from the material resources of the economy and optimal use of space; of tolerable social cohesion, from the family unit and public hygiene in living mass" 7 . That's how the architecture of this period becomes a concern of social consciousness.

According to Sara Lia Brysch ${ }^{8}$ architects such as Le Corbusier, Walter Gropius, Bruno Taut and Ernst May will research programs around new models of minimal standardized housing. These new neighborhoods gain the name of Sidlungen. Topics such as women's emancipation or inserting these in the labor market will encourage discussion of other debates that lead to optimization of housing space and consequently the kitchen itself. These investigations and debates give rise, at Frankfurt in 1926, to the "Frankfurt Kitchen" created by Margarete Schutte Lihotzky, which becomes the first modern kitchen. These and other problems of this period lead to an

\footnotetext{
5 "O aparecimento ex. nuovo de diversos núcleos de veraneio junto à costa, onde a casa unifamiliar de férias se apresenta como verdadeiro laboratório de experimentação projectual sobre a arquitectura doméstica" translated by author from the portuguese edition; Lobo, Susana, Arquitectura e Turismo: Planos e Projectos, as cenografias do lazer na costa Portuguesa, da $1^{a}$ República à Democracia, volume II, PhD thesis, DAFCTUC, Coimbra, 2012, P.777.

${ }^{6}$ Ramos, Rui Jorge García, A casa: arquitectura e projecto doméstico na primeira metade do século XX português, FAUP publicações, Porto, 2010.

7 "Durante o congresso os participantes procuraram formular um programa que conciliasse as exigências de criação física de espaço habitacional, a partir da economia de recursos materiais e do aproveitamento optimizado do espaço; da coesão social tolerável, a partir da unidade familiar e da higiene pública no convívio de massas" translated by author from the portuguese edition; Brysch, Sara Lia, Existenzminimum, a questão da habitação Mínima entre o Moderno e o Contemporáneo, master thesis, FAUP, Porto, 2011, P.1.

${ }^{8}$ Brysch, Sara Lia, Existenzminimum, a questão da habitação Mínima entre o Moderno e o Contemporâneo, master thesis, FAUP, Porto, 2011.
} 
optimization of the living space of the house, the creation of the family-type and consequently the construction of the model house.

At Weissenhof sidlungen, in Stuttgart, at the year of 1927, architects such as Gropius, Le Corbusier, Scharoun and others, directed by Mies Van der Rohe, create the exemplary residential scheme for the modern urban resident. In his town houses, Le Corbusier experiments the new concepts of what he thinks should be the modern house: the conquest of sun, air and space are his aims. "The view, the plants, the sun : are a conquest of the modern age" $"$. Le Corbusier builds one single family house and two town houses. In the town houses, the rooms are organized in a common space along with the social area and the kitchen; there is an optimization of the storage space and the beds are stacked in cupboards. The area is optimized in one big multi-functional room. The terrace is used as a panoramic garden over the city. The ground floor is organized in different storage and maid rooms. The concepts of Existenzminimum, are put in practice with an exterior purist language.

\subsection{Le Corbusier Houses of the decade of 1930}

At a certain time, there was a crescent need to balance the industrialization and the modern way of life, as well as a growing interest in building modern housing adapted to society and integrated into the local culture.

The study of culture and popular traditions will be the basis for creating a new architecture which is sensitive to the human needs.

In the work of Le Corbusier there are two initial moments: a first moment based in a purist language, revealed in his first works, predominately in the single-family houses built between 1920 and 1930; and a second moment in which the architect will be sensitive to local realities, as well as the physical characteristics of the plot, developed in the construction of small houses built in natural surroundings, after 1930.

In small holiday houses of the decade of 1930, Le Corbusier makes a big relationship with the vernacular architecture. Maison Errazuriz, Maison Mandrot, Maison aux Mathes, Maison de Week-End and Maison Murondins will be a perfect example of this acquaintance, which will be of great importance in the 1940/50 in Portugal.

\subsubsection{Maison Errazuriz, 1930, Chile.}

This house, which was never built, was to be located in a plot with a descending topography towards the shore of the Pacific Ocean. Traditional materials were to be used, not as a claim but as mere result of the impossibility for the use of industrial materials and of specialized construction labor at the site. The house was composed of two interlocking volumes. The interior makes use of pillars and beams in wood and thick granite walls, contrasting with the modern roof that was inverted (butterfly roof), but covered in traditional clay tiles. The ramp which gives access to the main bedroom is built in apparent stone, making evident the concept of "promenade architectural" in a craftwork approach.

\footnotetext{
9 "La vue, des plantes, le soleil : c'est une conquiste architecturale des temps modernes" translated by the author from the french edition ; Corbusier, Le, "Weissenhof à Stuttgart 1927", in Boesiger, W (dir.), Le Corbusier oeuvre complète, volume 1, Les Editions d`Architecture (Artemis), Zurich, 1964, P.152.
} 


\subsubsection{Maison Mandrot, 1930-1, Pradet, France.}

This vacation house is designed for Madame Mandrot, the first CIAM hostess. The house is designed in a remote location in Provence, Pradet, near Toulon. The house, which is organized in an L shape, is built by local entrepreneurs making use of a contrast between modern and traditional construction techniques. Concrete slabs and apparent local stone walls are put in contrast. The plot locates itself in a headland overlooking the landscape, to take part of this panoramic view the house organizes itself around an exterior patio created between house and guest's room. The relationship between nature and tradition is established by the house and the landscape, in its contemplation and the use of its local materials.

\subsubsection{Maison aux Mathes, 1935, France.}

This house located in a small pine forest in front of the Atlantic Ocean, is built on a restricted budget. Le Corbusier, unable to travel to the site, sent a local entrepreneur to supervise the building plans. The house was built in phases with the use of a well-established program and making use of pre-fab construction methods. Organized in a rectangular plan, all the rooms establish direct access to an open balcony. The organization is very similar in the upper and ground floor. The façade towards the ocean is frankly open, organized as a common balcony/corridor. The window panels protected of the sun by this transition space are divided in a metric structure that designs windows and doors constructed in wood, glass and pre-fab cement. This structure is painted in the primary colors of blue and red. The rear façade protects itself from the sun. Small square windows in the ground floor and a large longitudinal opening at the upper floor. The house is built in the dunes, preserving intact all natural elements of the plot "The house is built in the sand of the pine forest, without the creation of no artificial garden" $" 10$.

\subsubsection{Maison de Week-end, 1935, France.}

This vacation house is designed for a client who wanted to build a house camouflaged in the natural vegetation of the plot. Corbusier projected a small house built in stone walls combined with a concrete roof made in vaults covered by grass. This project introduces the mixture of different materials and their combination, wooden interiors in plywood, glass brick and clay brick walls and roofing in concrete. Being a small house, it is nonetheless very different in the spaces it creates. In the exterior, the garden is punctuated by different trees, combined with a small pavilion "kiosk" that is subtracted from the main volume of the house, creating a courtyard between the two. The interior space is organized in a big common room, with living, dining and kitchen functions. The bedroom is the only private division of the house. The green coverage camouflages the house in the garden, making the chimney and the lantern the only visible elements. "The petit maison de weekend, invokes the need to combine the principles of modern architecture with local materials and techniques, as well as it proposes to demystify the concept: a material, a use"11.

\footnotetext{
10 "La maison est plantée dans le sable de la forêt; kl n'y aucum jardin artificiel" translated by the author from thefrench edition ; Corbusier, Le, "Maison aux Mathes", in Bill. Max (dir), Le Corbusier oeuvre complète, volume 3, Les Editions d`Architecture (Artemis), Zurich, 1964, P.135.

11 "A petit Maison de week-end invoca por um lado a necessidade de conjugar os princípios da arquitectura moderna com materiais e técnicas locais, e por outro lado propõe a desmistificação do conceito : um material, um uso" translated by author from the portuguese edition; Rocha, Ana Patricia dos Santos, Casa das Marinhas, Arquitectura moderna e tradição portuguesa na obra de Viana de Lima, master thesis, FAUP, Porto, 2009, P.70.
} 


\subsection{The Cabanon}

The Cabanon was constructed in 1952, as a summer retreat for Le Corbusier. His idea was to build a modest summer house, nevertheless it was a great example of architecture "but concentrating on the interior and what he produced was in fact an example of the cultured art of living, of prime architectural merit" ${ }^{\prime 2}$.

The house was built in 1952. Corbusier and his wife Yvone, maintained a solid friendship with Thomas Rebutato, who was owner of a small restaurant in Roquebrune Cap-Martin. Rebutato had retired himself and bought a plot at Cap Martin where he built a bar-restaurant, Etoile de Mer. Thomas Rebutato made an exchange with Corbusier, giving him permission to use a part of his plot and build a small pavilion, the Cabanon. On the other hand, with the aim of valorizing his property, he commissioned Corbusier on the design of five touristic rooms known as Unité de camping, at the other side of the plot built in 1957.

The Cabanon, apparently a banal program, was an essential work in Corbusier`s career as an architect, participating in the contemporary architectural debate. A small house, done as an object that will demonstrate a very particular way of modern living, a model to be repeated.

The Cabanon, projected as an extension of the restaurant, follows its alignments of height and occupies a very small area (no more than 15 square meters). The license for its construction is obtained as an extension of the restaurant "chambre de villegiature", having the cabanon a doorway passage between the two. The plot is very narrow, and has an excellent view towards the bay of Monaco and Cap Martin. Being confronted with these natural restraints, Corbusier has no other solution as of building a small pavilion with the essential means for living in. The interior, is divided in two areas, access (made by a corridor of 70x366m) and a main living area. The living area is divided in sleeping (two individual beds) eating/lounge (organized with a table and two stalls) and bath (organized with a lavatory and an individual toilet). The plan libre, one of the main conceptual points of the cabanon, organizes the entire house by the use of fixed furniture.

The Modulor works as a human figure that designs and dimensions the furniture, an essential part of the organization of the house, which is produced with a level of detail near to arts and crafts.

The hut is camouflaged in the Mediterranean vegetation, covered with rafts of wood, reminding us of the primitive cabin hut. The interior in contrast to the rough exterior, is all lined in plywood and different colored panels. The shutters that enclose all the house show the level of detail that was put in the entire project. They are designed as movable paintings, being mirrors and paintings at the same time "In short, they bring the outdoors in and vice versa, with a play of interior contemplation by which the outside becomes the inside and these are projected out, while the two aspects blend together more and more and make the expansion of the virtual space more effective" ${ }^{, 13}$.

This small pavilion represents and condenses the importance of the minimum space for modern living that was being debated from 1929 (CIAM congress) onwards. Corbusier summarizes this debate in his small Cabanon in the decade of 1950, defining the minimum space for two living people and combining it with a plastic and spiritual approach.

\footnotetext{
${ }^{12}$ Alison, Filippo, Le Corbusier, L'Interno del cabanon, Le Corbusier 1952 Cassina 2006, Trienal and Electa, Milano, 2006, P.20.

${ }^{13}$ Alison, Filippo, Le Corbusier, L'Interno del cabanon, Le Corbusier 1952 Cassina 2006, Trienal and Electa, Milano, 2006, P.24.
} 


\subsection{Holiday houses in Portugal between 1940 and 1974}

In an attempt to establish a parallel between the Existenzminimum, the work of Le Corbusier in the decade of 1930, the Cabanon and holiday houses in Portugal of the 1950s, I made an investigation in a number of case studies in Portugal where the principles were the same. I will present two in some detail in this paper.

\subsubsection{Ribeiro da Silva house - Ofir, Fernando Távora, 1957.}

Ribeiro da Silva House in Ofir is one of the most important holiday houses built in Portugal in the decade of 1950. In this house, architect Fernando Távora will establish a dialogue between the Modern Movement and the Portuguese vernacular architecture. Távora makes a reinterpretation of Le Corbusier in this house, visible in some of its main characteristics.

Ofir as a summer resort has its origin in the village of Fão, a fishing village located in the North of Portugal. Ofir will start to be developed in 1945. Its initial development is done around the main street (Avenida António Veiga) that establishes relation between the village of Fão and the sea. Later, the main Pine forest is divided in big plots where detached houses were built.

According to Tiago Bragança Borges ${ }^{14}$, Ofir is constructed from the initiative undertaken by the Sociedade de Engenheiros Reunidos of Oporto headed by Raul de Sousa Martins, which aims to create in Ofir, a touristic resort for the northern elite. "Similar to Rodízio, Ofir has also taken a leading role with respect to the beginning of the proliferation of holiday houses in Portugal"15.

At Ofir, the architect Alfredo Angelo de Magalhães will be the leading architect, in the construction of the first touristic facilities such as the Hotel and Restaurant Ofir, which will launch the summer resort within the bourgeoisie of Oporto. This architect will be the responsible for the first houses built between 1945 and 1947.

The Ribeiro da Silva house is projected in 1955 and the execution takes two years. It is located in a big plot in the main pine forest of Ofir, towards the North of the resort. In this project, Távora feels the need to create a new integrated architecture. For this he will make use of the plot and its natural features, using the topography, the winds, the solar orientation and the best views towards the nearby river.

In order to establish a contrast between modern and vernacular architecture, Távora uses traditional materials and construction techniques, such as pitched roofs covered with clay tiles, wooden joinery in the windows and the roof trusses, natural stone pavements in the floors and granite stone walls painted in white.

On the other hand he uses modern concepts and building techniques, concrete used in the construction of the roof slabs and the chimney, the design of the openings, the organization of the house in different functional zones and the standardized distribution of the sleeping areas.

The different areas of the house are organized in three zones. Social, private and services, these expand towards garden patios, establishing an open relationship between interior and exterior. The living room opens itself towards a natural dune where a water fountain is located. The services with kitchen, maid bedroom, storage and service bathroom open to a rear patio. The sleeping area, with five bedrooms and bathrooms is organized in a

\footnotetext{
${ }^{14}$ Borges, Tiago Bragança, Ofir do Arquitecto Alfredo Ângelo de Magalhães, master thesis, IST-UTL, Lisboa, 2012.

15 “À semelhança do Rodízio, Ofir vem também assumir um papel de destaque no que concerne ao início da proliferação das casas de férias em Portugal" translated by author from the portuguese edition; Dantas, Joana Croft de Moura Drummond, A casa de férias como habitação Mínima em Portugal, master thesis, IST-UTL, Lisboa, 2011, P.111.
} 
standardized way, resembling to the Existenzminum theories. The beds are put against the wall in a longitudinal way, with individual storage cupboards.

Le Corbusier stands closely in the work of Távora, and is easily seen in the architectural signs that are present in the house at Ofir. The cupboard/shelve in concrete in the eating area, is directly related with the storage/shelve in the week-end house near Paris. The openings of the bathrooms façade, designed as an abstract drawing are closely related with Ronchamp or the rear faced of Maison aux Mathes. The main concept of using stone walls in contrast with concrete slabs, can be related to Le Corbusier`s approach at Maison Mandrot. The thick granite walls painted in white at Ofir and in Maison de week-end show direct similarities that can be seen in the images presented. Using modern architecture concepts with traditional materials and techniques are introduced by Távora in Ofir, resembling us of Corbusier experiences in the 1930.
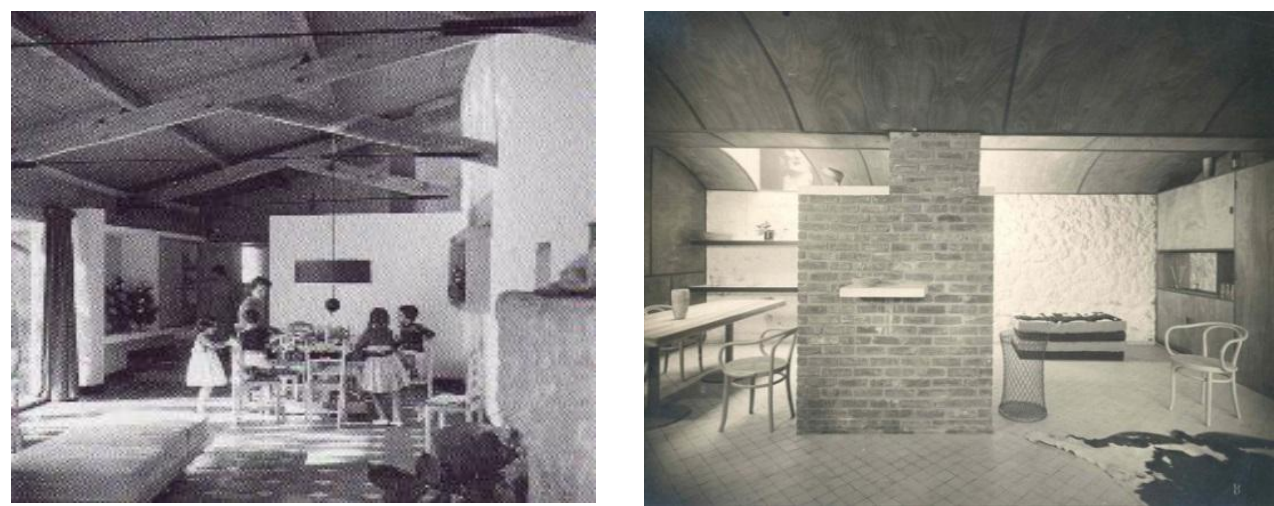

1. Ribeiro da Silva House, Ofir.

2. Maison de week end, Paris.

Fernando Távora will establish in this house a "third way", working as a milestone in the transition of modern architecture in Portugal. It makes a relation between modern and vernacular, questioning the absolute principles of the modern movement and giving them a cultural and local value. Worldwide this issue was being tested by architects of 1950/60, such as Coderch in Spain or Aalto in Finland.

\subsubsection{Pereira da Costa houses - Moledo do Minho, Carlos Carvalho Dias, 1963.}

Moledo Minho was already a holiday resort for the elite since the beginning of the century. The summer chalets of the elite families were located on Avenida de Santana above the railway. According to João Cerqueira ${ }^{16}$ in the 1940s, Moledo has an urban growth result of the urbanization plan created in 1941 by David Moreira da Silva, which amends the general plan of improvements from 1929, designed by Carlos Ramos. According to the author, the plan divides the Camarido pine forest, in plots that are never less than a thousand square meters. By the 1950, there were no buildings on this new core, only warehouses for fishermen and small rental holiday houses. Between the decade of 1950 and 1970, detached holiday houses start to be built in these plots.

The Pereira da Costa houses are built in Moledo do Minho in 1963, by architect Carlos Carvalho Dias and are a result of his CODA project (final course project). The project is a set of evolutionary minimum houses for the pinewood of Camarido. The initial project, was conceived as small settlement of houses, but only two were built.

\footnotetext{
${ }^{16}$ Cerqueira, João Francisco Delgado, A casa de férias do concelho de Caminha: entre a revisão vernacular da Modernidade e a livre expressão de estilos contemporâneos, master thesis, FLUP, Porto, 2003.
} 
The pine forest, its topography and its vegetation are maintained in an attempt to approach the existing natural settings. As in Maison aux Mathes the pine forest and the dune is maintained in all its original aspects. The two buildings are quite far apart and approach two different streets, establishing individualized access.

The South house is organized in a rather functional way and easily understood from the exterior. Two clearly distinct, day and night areas. The daytime area includes kitchen, common living room and toilet, the night area organizes three small rooms and a toilet. From the outside these two areas with pitched roofs appear as very evidently connected by a connection corridor with a flat roof.

The organization of the South house, is clearly modern, the architect establishes the separation between functional zones in the same house, the rooms are like small cells where the openings appear in small dimensions, resembling us of the cabins vessels, the Cabanon, and the theories of the Existenzmnimum.The living space is situated between two patios, one in the East that is the main access to the house and the other to the West in open communion with the pine forest, extending itself in a lounge patio paved in granite.

The North house is designed in a more compact way. It organizes its different areas in a more common approach, but uses the natural topography of the plot to divide the areas in sleeping and living, making use of stairs to adapt to the natural topography.

The exterior architectural design of these two houses, still show some similarities between the modern and the rustic cabin. These contrasts are evident in the use of granite walls in apparent contrast with white plastered walls. Wooden shutters painted red enclosing small windows designed as abstract paintings resembling us the small windows of Maison aux Mathes in contrast with large glass panels of the living rooms using iron frames with a geometric design.
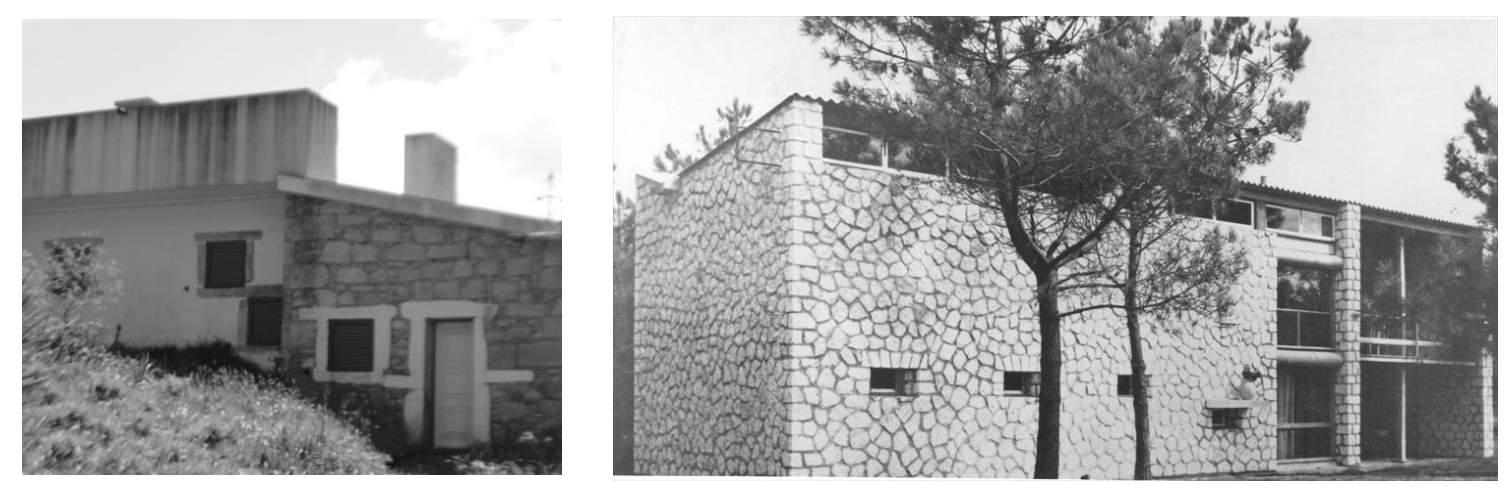

3. Pereira da Costa Houses, (North house), Moledo do Minho

4. Maison aux Mathes, Les Mathes.

The pitched roofs, initially covered in fiber cement in undulated panels are later replaced by clay tiles, establishing a clear contrast with the flat roofs of the connection corridors.

This is a transitional work, where the modern comes into contact with a reinterpretation of vernacular architecture, similar to Le Corbusier`s approach in his summer houses of the 1930s. In the way Távora establishes this connection in Ofir in the decade of 1950, other Portuguese architects started to test these possibilities of transition, questioning the modern movement principles and integrating architecture with a cultural and local approach. 


\section{Conclusions}

Summer houses in Portugal between 1940 and 1974 are assumed as a research laboratory in the production of modern architecture, testing the transition stage between modern and vernacular and creating new models to live a house.

The architects, largely influenced by the work of Le Corbusier, produced modern architecture with local materials and techniques in contrast to the use of modern materials such as concrete. Modern functional distributions and standardized areas, directly relate with the experiences of the Existenzminumum, organize the houses, with large living rooms directly related with the exterior and small sleeping alcoves adapted to the dimensions of the man.

The program of the summer house will imprint a period of acceptance of modern architecture in Portugal, made possible by the acceptance of an uncompromising modern way of life, where the domestic space of the house is transformed.

\section{Acknowledgements}

The author acknowledges the courtesy for the images submitted with permission by LA Fondation Le Corbusier, and BLAU Publisher, and for the books available at the library of Faculdade de Arquitectura da Universidade do Porto.

\section{Source of Images}

Image 1. Sousa, Rui Morais de, Fernando Távora, Blau, Lisboa, 1993.

Image 2. Fondation Le Corbusier/ADAGP

Image 3. Freitas, Tiago, Moledo do Minho, 2015.

Image 4. Fondation Le Corbusier/ADAGP

\section{Bibliography/references}

Alison, Filippo, Le Corbusier, L`Interno del cabanon: Le Corbusier 1952 Cassina 2006, Trienal and Electa, Milano, 2006.

Borges, Tiago Bragança, Ofir do Arquitecto Alfredo Ângelo de Magalhães, master thesis, IST-UTL, Lisboa, 2012.

Brysch, Sara Lia, Existenzminimum, A questão da habitação Mínima entre o Moderno e o Contemporâneo, master thesis, FAUP, Porto, 2011.

Cerqueira, João Francisco Delgado, Casa de férias do concelho de Caminha: entre a revisão vernacular da Modernidade e a livre expressão de estilos contemporâneos, master thesis, FLUP, Porto, 2003.

Boesiger, W; Bill, Max (Dir.) Le Corbusier oeuvre complète, Les Editions d`Architecture (Artemis), Zurich, 1964.

Dantas, Joana Croft de Moura Drummond, A casa de férias como habitação Mínima em Portugal, master thesis, IST-UTL, Lisboa, 2011.

Lobo, Susana, Arquitectura e Turismo: Planos e Projectos, as cenografias do lazer na costa Portuguesa, da $1^{a}$ República à Democracia, volume II, PhD thesis, DAFCTUC, Coimbra, 2012.

Ramos, Rui, A casa, Arquitectura e Projecto doméstico na primeira metade do século XX Português, FAUP publicações, Porto, 2010. 
Rocha, Ana Patrícia dos Santos, Casa das Marinhas, Arquitectura moderna e tradição portuguesa na obra de Viana de Lima, master thesis, FAUP, Porto, 2009.

Tostões, Ana, A idade maior. Cultura e tecnologia na arquitectura moderna potuguesa, Faup ed. , Porto,2015 [2003], pp.302.

Tostões, Ana, "Casas de Férias modernas, anos 50 e estilo contemporâneo- A utopia de uma doce vida", in Jornal de Arquitectos, $N^{o}$ 196, Ordem dos Arquitectos, Lisboa.2000, pp. 45-53. 